\title{
Binding Antibodies to Attached Cells or Tissues in Preparation for Staining
}

\author{
Scott J. Rodig
}

Cells for staining are usually prepared from one of three sources: adherent cells, suspension cells, or whole tissues. Antibodies generally are applied directly to the area of the cells or tissues that is being studied. The antibodies can be labeled directly or they can be detected by using a labeled secondary reagent that will bind specifically to the primary antibody. Detection reagents for cell staining can be labeled with fluorochromes, enzymes, gold, or iodine.

\section{MATERIALS}

It is essential that you consult the appropriate Material Safety Data Sheets and your institution's Environmental Health and Safety Office for proper handling of equipment and hazardous materials used in this protocol.

Cells or tissues that have been attached to a substrate (coverslips, slides, or plates), fixed, and washed Phosphate-buffered saline, supplemented with $1 \%$ Triton X-100 or NP-40 if necessary

See Step 4.

Primary antibody solution, diluted (see Step 2)

All dilutions of the primary antibody must be performed in protein-containing solutions. For example, use phosphate-buffered saline (PBS) containing 3\% bovine serum albumin (BSA).

Secondary detection reagent, labeled (as needed, if using unlabeled primary antibodies) (see Step 6) It is essential to perform all dilutions in a protein-containing solution such as 3\% BSA in PBS or 1\% immunoglobulin (prepared from the same species as the detection reagent) in PBS. Useful secondary reagents include antiimmunoglobulin antibodies, Protein A, or Protein G. They can be labeled with enzymes, fluorochromes, gold, or iodine; see Step 6 for reagent requirements. Labeled secondary reagents can be purchased from several suppliers or can be prepared as described in Introduction: Labeling Antibodies (Berg and Fishman 2020).

Equipment

Humidified chamber

See Step 1.

1. Place coverslips, slides, or plates containing samples in a humidified chamber. Slides or coverslips can be placed in a Petri dish containing a water-saturated filter. Coverslips are best placed

From the Antibodies collection, edited by Edward A. Greenfield.

(C) 2020 Cold Spring Harbor Laboratory Press

Cite this protocol as Cold Spring Harb Protoc; doi:10.1101/pdb.prot099705 
on a layer of Parafilm; this helps to stop the antibody solution from rolling off the edge of the coverslip and makes it easy to pick up the coverslips with fine forceps, because the Parafilm is compressible.

2. Add the primary antibody solution.

\section{For Unlabeled Primary Antibodies}

i. Monoclonal antibodies are best applied as tissue culture supernatants (specific antibody concentration of $20-50 \mu \mathrm{g} / \mathrm{mL}$; use neat). Ascites fluids, purified monoclonal and polyclonal antibodies, and crude polyclonal sera should be tested at a range of dilutions aimed at producing specific antibody concentrations between 0.1 and $10 \mu \mathrm{g} / \mathrm{mL}$. If the specific antibody concentration of the antibody sample is unknown, prepare and test $1 / 10,1 / 100,1 /$ 1000 , and $1 / 10,000$ dilutions of the starting material.

\section{For Labeled Primary Antibodies}

ii. Primary antibodies can be labeled with enzymes, fluorochromes, or iodine as described in Introduction: Labeling Antibodies (Berg and Fishman 2020). They should be assayed at several dilutions in preliminary tests to determine the correct working range. Too-high concentrations will yield high backgrounds; too-low concentrations will make detection difficult. The correct concentration will depend on both the abundance of the antigen under study and the specificity of the antibody.

3. Incubate the coverslips, slides, or plates for a minimum of $30 \mathrm{~min}$ at room temperature in the humidified chamber.

For some reactions, prolonged incubations of up to $24 \mathrm{~h}$ can increase sensitivity.

4. Wash the samples in three changes of PBS over $5 \mathrm{~min}$. This buffer may be supplemented with $1 \%$ Triton X-100 or NP-40 to help with any background problems.

5. If the primary antibody is labeled, proceed to detection (see, e.g., Protocol: Detecting Horseradish Peroxidase-Labeled Cells [Rodig 2019a], Protocol: Detecting Alkaline Phosphatase-Labeled Cells [Rodig 2019b], Protocol: Detecting $\boldsymbol{\beta}$-Galactosidase-Labeled Cells [Rodig 2020a], Protocol: Detecting Gold-Labeled Cells [Rodig 2019c] or Protocol: Detecting Iodine-Labeled Cells [Rodig 2019d]). If the primary antibody is unlabeled, continue with Step 6.

6. Apply the labeled secondary reagent.

\section{For Enzyme-Labeled Reagents}

i. If using a commercial preparation, test dilutions of the secondary antibodies from 1/50 to $1 /$ 1000. Alkaline phosphatase-labeled reagents should be handled using Tris-buffered saline, not PBS. When using horseradish peroxidase-labeled reagents, the buffers used for dilution and washing should not contain sodium azide.

\section{For Fluorochrome-Labeled Reagents}

ii. If using commercial preparations, test dilutions from $1 / 10$ to $1 / 300$.

\section{For Gold-Labeled Reagents}

iii. Wash the gold particles once in PBS. Dilute in PBS containing 1\% gelatin and add to the specimen. 
S.J. Rodig

\section{For lodine-Labeled Reagents}

iv. Add the iodinated antibody at $\sim 0.1 \mu \mathrm{g} / \mathrm{mL}$. Usually, specific activities between 10 and $100 \mu \mathrm{Ci} / \mu \mathrm{g}$ are used.

7. Incubate with the labeled secondary reagent for a minimum of $20 \mathrm{~min}$ at room temperature in the humidified chamber. For gold-labeled reagents, observe periodically under the microscope until a satisfactory signal is obtained.

8. Wash in three changes of PBS (or Tris saline) over $5 \mathrm{~min}$.

9. Proceed to detection (see, e.g., Protocol: Detecting Horseradish Peroxidase-Labeled Cells [Rodig 2019a], Protocol: Detecting Alkaline Phosphatase-Labeled Cells [Rodig 2019b], Protocol: Detecting $\boldsymbol{\beta}$-Galactosidase-Labeled Cells [Rodig 2020a], Protocol: Detecting Gold-Labeled Cells [Rodig 2019c] and Protocol: Detecting Iodine-Labeled Cells [Rodig 2019d]).

\section{REFERENCES}

Berg EA, Fishman JB. 2020. Labeling antibodies. Cold Spring Harb Protoc doi: 10.1101/pdb.top099242.

Rodig SJ. 2019a. Detecting horseradish peroxidase-labeled cells. Cold Spring Harb Protoc doi: 10.1101/pdb.prot099713.

Rodig SJ. 2019b. Detecting alkaline phosphatase-labeled cells. Cold Spring Harb Protoc doi: 10.1101/pdb.prot099721.
Rodig SJ. 2019c. Detecting gold-labeled cells. Cold Spring Harb Protoc doi: 10.1101/pdb.prot099754.

Rodig SJ. 2019d. Detecting iodine-labeled cells. Cold Spring Harb Protoc doi: 10.1101/pdb.prot099762.

Rodig SJ. 2020a. Detecting $\beta$-galactosidase-labeled cells. Cold Spring Harb Protoc doi: $10.1101 /$ pdb.prot099739. 


\section{Binding Antibodies to Attached Cells or Tissues in Preparation for Staining}

Scott J. Rodig

Cold Spring Harb Protoc; doi: 10.1101/pdb.prot099705

\begin{tabular}{|c|c|}
\hline $\begin{array}{r}\text { Email Alerting } \\
\text { Service }\end{array}$ & Receive free email alerts when new articles cite this article - click here. \\
\hline $\begin{array}{r}\text { Subject } \\
\text { Categories }\end{array}$ & $\begin{array}{l}\text { Browse articles on similar topics from Cold Spring Harbor Protocols. } \\
\text { Antibodies (119 articles) } \\
\text { Antibodies, general (289 articles) } \\
\text { Immunostaining (139 articles) } \\
\text { Immunostaining Cells (51 articles) } \\
\text { Immunostaining Tissues ( } 84 \text { articles) } \\
\text { Immunostaining, general (94 articles) }\end{array}$ \\
\hline
\end{tabular}

